\title{
ADAPTIVE POTENTIAL OF BUCKWHEAT TO ENVIRONMENTAL CONDITIONS AND WAYS OF INCREASING ITS ECOLOGICAL SUSTAINABILITY
}

\section{Averchev O. V.}

\section{INTRODUCTION}

The grain farming plays a key role in the economy of the state. In order to ensure the efficient functioning of the grain farming, it is important to fully meet the country's domestic grain requirements and increase its export potential. For Ukraine, increasing grain growing is of strategic importance for raising the national economy, since its successful development creates the conditions for the effective functioning of a number of related industries. Improving the efficiency of grain productivity is one of the most important tasks on which the food security of the country depends. It should be implemented both at the state and regional levels, where food supply issues are addressed ${ }^{1}$.

Growing and consumption of cereal crops by the population of Ukraine is traditional. Cereals are an important component of the Ukrainians diet.

The main cereal crops grown in Ukraine are buckwheat, Panicum and rice. All of them are of Asian origin, but the first two can be confidently attributed to traditionally Slavic crops. In Tsarist Russia buckwheat and Panicum were sown no less than wheat, and buckwheat groats and millet occupied a significant place in the population's feeding and were perhaps the largest export items to other countries. Thus, in the beginning of the XIX century, over 4 million hectares were sown with buckwheat, which made $3 / 4$ of its sowings in the world ${ }^{2}$, and the share of Panicum in some regions was $40-80 \%$ of the total grain area ${ }^{3}$.

Buckwheat has long been sown in Russia and Ukraine in both main and post-harvested sowings. It is also was sown as a replacement $\operatorname{crop}^{4,5,6}$. Back in

${ }^{1}$ Погріщук Б.В. Організаційно-економічні умови функціонування зернопродуктового підкомплексу України: аспекти оптимізації [Текст] / Б. В. Погріщук // АгроСвіт. - 2010. № 4. - C. 13-17.

2 Аверчев О.В. Адаптивний потенціал проса, гречки та шляхи його підвищення / О.В. Аверчев, 3.М. Тимофеєв // Таврійський науковий вісник: збірник наукових праць. Вип. 24. - Херсон, 2002. - С. 36-41.

${ }_{3}$ Кадирова Ф.Е. Гречиха и просо - ценные крупяные культуры / Ф.Е. Кадирова // Земледелие. - № 3. - 2006. - С. 11.

${ }_{4}$ Крестьянникова Т.М. Пожнивное выращивание гречихи / Т.М.Крестьянникова / [Под ред. И.Н. Елагина] // Биология и возделывание гречихи. - М.: Сельхозиздат, 1962. С. 273-302.

${ }^{5}$ Аверчев О.В. Адаптивний потенціал проса, гречки та шляхи його підвищення / О.В. Аверчев, 3.М. Тимофеєв // Таврійський науковий вісник: збірник наукових праць. Вип. 24. - Херсон, 2002. - С. 36-41. 
1913-1916, some biological features of buckwheat were presented, and the first studies on the intercrop of buckwheat in irrigated lands of southern Ukraine were conducted at the former Kherson Agricultural Research Station in 1924-1925 by Podgorny P.I.

Due to a number of biological features of buckwheat, the different response of this crops to the ecological factors that arise during the growing season are known, and as a result its yield greatly differs over the years.

Buckwheat - Fagopyrum esculentum Moench. (Synonyms: Fagopyrum fagopyrum (L.) Karst., Fagopyrum sagittatum Gilib., Fagopyrum vulgare Hill, Polygonum fagopyrum L.), belongs to the Polygonales, family Polygonacea, genus Fagopyrum P. Mill.

Until recently, two types of arable buckwheat (common buckwheat, Tatar buckwheat) and seven types of wild buckwheat were known. However, the collection is updated annually with new samples, and the updated classification of buckwheat testifies to the existence of 14 types of buckwheat ${ }^{7}$.

Among all species, the main place takes common buckwheat. Currently, its geography includes Russia, Ukraine, Belarus, Kazakhstan, Serbia, Croatia, Poland, as well as Japan, China, Mongolia, Korea, USA, Canada, Bhutan and Brazil. In other countries, buckwheat is grown on small areas, mainly as a replacement crop or green manure crop; it is given less attention and often attributed to low-yielding cereals ${ }^{8,9}$.

In fact, in terms of grain use in the national economy buckwheat is not inferior to the main cereal crops, and in some biochemical indicators and dietary characteristics buckwheat grain exceeds them. In addition, buckwheat products are environmentally friendly and low investment in production, which is of particular importance in the modern world ${ }^{10,11}$.

Buckwheat in a role of intercrop is attributed to the environmentally friendly direction of intensification of agricultural production in Ukraine $^{12,13}$. Thus, the word "green", which labels organic produce and

${ }^{6}$ Калус Ю.А. Влияние условий выращивания и сортовых особенностей гречихи на ее урожай в южной степи Украины: автореф. дис. ... канд. с.-х. наук: спец. 06.01.09 растениеводство / Ю.А. Калус. - Одесса, 1973. - 12 с.

7 Кацов И.И. Роль агроклиматического фактора в реализации потенциала сорта Сумчанка / И.И. Кацов, В.М. Клюс, В.Г. Егоров // Зерновые культуры [Мат. I Межгос. конгр. производ. греч.]. - Спец. вып. № 2. - 1993. - С. 35-37.

${ }_{8}$ Єфіменко Д.Я. Круп'яні культури / Д.Я. Єфіменко, І.В.Яшовський, Б.І.Лактіонов, I.М. Фрич / [За ред. І.В. Яшовського]. - К.: Урожай, 1982. - 160 с.

${ }^{9}$ Гораш О.С. Екологічна різноякісність насіння гречки / О.С. Гораш // Збірник наукових праць. - Вип. 8. - Кам'янець-Подільський, 2000. - С. 26-29.

${ }^{10}$ Алексеєва О.С. Гречка / О.С. Алексеєва. - К.: Урожай, 1976. - 131 с.

11 Ефименко Д.Я. Установление оптимальных сроков посева гречихи по уровню температурного режима почвы / Д.Я. Ефименко. - М.: ВДНХ СССР, 1988. - 6 с.

${ }_{12}$ Крестьянникова Т.М. Пожнивное выращивание гречихи / Т.М. Крестьянникова / [Под ред. И.Н. Елагина] // Биология и возделывание гречихи. - М.: Сельхозиздат, 1962. C. 273-302. 
indicates its organic origin, is associated with a narrow range of crops, among which buckwheat is prominent ${ }^{14}$.

Due to growing demand for eco grain and relatively increasing income, buckwheat displaced spring wheat in the United States ${ }^{15,16}$, from year to year, as well as many other crops in crop rotation where buckwheat prevents the development of harmful organisms and contributes to clearing fields of weed. Thus, intercrops of buckwheat in Missouri (USA) provide more additional income than soybeans ${ }^{17}$. In the Czech Republic, the environmental and dietary properties of grain led to an increase in organic buckwheat production in 1997 (more than 200\% compared to 1990), and in 1999, from the total harvest of 1,500 tons the share of organic buckwheat grain was 520 tons, and more than 30 types of products are produced from its grain ${ }^{18}$. Recently, buckwheat is in high demand in Japan, where at own production of 20 thousand tons of grain per year, it is consumed up to 110 thousand tons of grain so the rest is imported from China, the US and Canada. Buckwheat sowings are expanding in Australia, where new acreage is being planted in the south of the country. Thus, in 1995, its crops first appeared in the arid state of Victoria .

Considering the fact that the Steppe zone is too plowed (82.8\%), including the Kherson region by $89.1 \%$, and the area of arable land per capita in Ukraine is not increasing but decreasing, it becomes clear that production growth of crops can be achieved by growing two crops a year from the same area. It should be noted that even at a yield of $400-500 \mathrm{~kg} / \mathrm{ha}$, buckwheat covers all the costs of its growing ${ }^{19}$. Buckwheat is of particular relevance in irrigated areas where it is proven by practice that the agro-climatic resources of southern Ukraine completely satisfy the needs of buckwheat for the main factors of life.

${ }^{13}$ Калус Ю.А. Влияние условий выращивания и сортовых особенностей гречихи на ее урожай в южной степи Украины: автореф. дис. на соискание уч. степени канд. с.-х. наук: спец. 06.01.09 - растениеводство / Ю.А. Калус. - Одесса, 1973. - 12 с.

${ }_{14}$ Епифанов В.С. Стабильный урожай гречихи / В.С.Епифанов, И.А. Яковлев // Зерновые культуры. - 1989. - № 5. - С. 39.

${ }^{15}$ Xianshi G. Yingyong shengtai xuebao / G.Xianshi // Chin. J. Appl. Ecol. - 1999. - V. 10. № 5. - P. 563-566.

16 Аверчев О.В. Адаптивний потенціал проса, гречки та шляхи його підвищення / О.В. Аверчев, 3.М. Тимофеєв // Таврійський науковий вісник: збірник наукових праць. Вип. 24. - Херсон, 2002. - С. 36-41.

${ }^{17}$ Xianshi G. Yingyong shengtai xuebao / G.Xianshi // Chin. J. Appl. Ecol. - 1999. - V. 10. № 5. - P. 563-566.

18 Ефименко Д.Я. Установление оптимальных сроков посева гречихи по уровню температурного режима почвы / Д.Я. Ефименко. - М.: ВДНХ СССР, 1988. - 6 с.

19 Аверчев А.В. Пайова участь досліджуваних факторів у врожайності гречки повторних посівів на зрошуваних землях півдня України / А.В.Аверчев, Ю.В. Аверчев // Збірник наукових праць Уманської державної академії. - Вип. 53. - Умань, 2001. C. 40-43. 


\section{Buckwheat and heat}

Although buckwheat is less demanding for heat than, for example, Panicum, it is attributed to thermophilic plants and an important factor in ensuring even sprouts is the absence of low temperatures during the initial growth period. It is known that the sprouts are damaged at a temperature of $2^{\circ} \mathrm{C}$, and at $-4^{\circ} \mathrm{C}$ sowings die completely. The cotyledonary leaves and the first real leaves are the most affected by frosts ${ }^{20}$. The crucial role of heat in the first days of life is indicated by the following: the minimum air temperature at $10^{\circ} \mathrm{C}$ and below during the germination of seeds determines the further growth and development of buckwheat plants.

Obtaining even sprouts also requires a certain soil temperature. The most favorable temperature for seed germination is $27^{\circ} \mathrm{C}$, although the soil temperature range is quite wide - from 7 to $40^{\circ} \mathrm{C}$. Thus Trigub O.V. found that the middle-ripe group is characterized by the highest thermo-resistance in the early stages of plant development, the late-ripening sea group of varieties has the lowest thermos-resistance.

Seed germination intensity and rapid emergence of seedlings are of particular importance to buckwheat, as indicated by the close correlation between germination energy and yield $(r=0.99-0.90)^{21}$. The future yield is also highly dependent on the success of the II-IV stages of organogenesis. If the optimal conditions are not created at these stages, including at the beginning of the first true leaf unfolding stage, even the most favorable conditions in the future cannot increase the yield ${ }^{22}$.

According to the generalized data of some authors, the minimum temperature for germination of buckwheat seeds is $5-6^{\circ} \mathrm{C}$, for emergence of seedlings $-8^{\circ} \mathrm{C}$, and during the formation of generative organs, fruiting and ripening $-10-12^{\circ} \mathrm{C}$.

After the appearance of the second pair of true leaves, buckwheat begins to grow vegetative mass. The growth of leaf surface takes 3-6 weeks. During this period (before the budding phase) buckwheat is less demanding for temperature due to slow growth. Under optimal conditions, flowering occurs on 17-22 days in the early-maturing varieties and 23-28 - in the

${ }^{20}$ Аверчев О.В. Адаптивний потенціал проса, гречки та шляхи його підвищення / О.В. Аверчев, 3.М. Тимофеєв // Таврійський науковий вісник: збірник наукових праць. Вип. 24. - Херсон, 2002. - С. 36-41.

${ }^{21}$ Крестьянникова Т.М. Пожнивное выращивание гречихи / Т.М.Крестьянникова / [Под ред. И.Н. Елагина] // Биология и возделывание гречихи. - М.: Сельхозиздат, 1962. - C. 273-302.

${ }^{22}$ Когут В.В. До питання впливу метеорологічних факторів на урожайність гречки сорту Вікторія / В.В. Когут // Збірник наукових праць. - Вип. 8. - Кам'янець-Подільський, 2000. - C. 59-61. 
middle-ripening varieties. From this moment, the growth and development of plants become faster ${ }^{23}$.

With the onset of flowering, the generative period of plant development begins. During this period, most of the leaves and shoots and 3/4 of the organic matter crop are formed ${ }^{24}$. The process of flowering in buckwheat is extended over time and lasts 4-6 weeks depending on the group of ripeness of varieties and weather conditions. Flowering takes place not at the same time both within the plant and one truss. For example, flowers on one plant bloom for 30-60 days, on the truss - 10-15 days. At the time of bud formation and flowers blooming, when their pollination begins, there is another threat - dry air, which causes the plants to wither, even with sufficient moisture in the soil. Dry hot weather with a temperature of $25^{\circ} \mathrm{C}$ and higher during this period dries the anthers and causes "fervor" of the fruit-forming elements, as a result of which the grain is shrinked or not formed at all. It is set that under favorable conditions, buckwheat grain is formed 10 days after pollination, after which reserve oils, starch and protein are actively accumulated in the embryo and endosperm. After 20 days dry matter accumulation is completed, the water content in the endosperm decreases at a rate of $850 \mathrm{~g} / \mathrm{kg}$ on 6th day, up to $220 \mathrm{~g} / \mathrm{kg}$ on 16th day after pollination. Under unfavorable conditions, the endosperm does not develop and the weevil does not form, although the pericarp reaches normal dimensions of the ripe fruit ${ }^{25}$.

The direct link between the high daytime temperatures during the buckwheat flowering-fruit formation period and damage of the fruit elements and ovaries has been extensively enlightened in different works. Scientists estimate that temperatures above $25^{\circ} \mathrm{C}$ significantly reduce fruit inception and grain yield. At the same time, it was found that the July temperature of $26^{\circ} \mathrm{C}$ and higher during 18 days causes a fervor and reduces the grain yield by $500-600 \mathrm{~kg} / \mathrm{ha}$, and not only the fertilized ovaries dry, but also green fruits. A number of authors also point to the "criticality" of the "flowering - fruit formation" period in relation to the thermal regime. Other scientists provide data on the inverse dependence of buckwheat crop on the temperature of the critical period $(r=-0.33)$ and the close relationship with the temperature in the inter-phase period "flowering - ripening" $(r=0,86)$.

${ }^{23}$ Аверчев А.В. Пайова участь досліджуваних факторів у врожайності гречки повторних посівів на зрошуваних землях півдня України / А.В.Аверчев, Ю.В. Аверчев // Збірник наукових праць Уманської державної академії. - Вип. 53. - Умань, 2001. - С. 40-43.

${ }^{24}$ Борисова Н.А. Урожайность гречихи по влагообеспеченности на юге Центрального региона Нечерноземной зоны / Н.А.Борисова, М.К. Каюмов // Научные труды РГАЗУ. M., 2002. - C. 44-46.

${ }^{25}$ Аверчев О.В. Адаптивний потенціал проса, гречки та шляхи його підвищення / О.В. Аверчев, 3.М. Тимофеєв // Таврійський науковий вісник: збірник наукових праць. Вип. 24. - Херсон, 2002. - С. 36-41. 
The most favorable temperature for the formation of vegetative and generative organs ranges from $20-25^{\circ} \mathrm{C}$, during flowering period the need for buckwheat in heat is lower, and in the period of fruit-formation it is higher. The range from 17 to $21^{\circ} \mathrm{C}$ is considered to be the optimal daily temperatures for flowering.

According to many years of research by the Polish researcher Rushkowski M., at the end of flowering period of buckwheat, temperature should not exceed $17-19^{\circ} \mathrm{C}$ with precipitation amount $20-30 \mathrm{~mm}$ and humidity $50-60 \%$, and in the period of ripening it should be $17-20^{\circ} \mathrm{C}$ with small precipitation.

Due to the fact that buckwheat actively grows and develops at an average daily temperature of $15-18^{\circ} \mathrm{C}$ - this is a condition for maximum and effective use of post-harvest heat before frosts.

The uneven flowering of buckwheat leads to the simultaneous ripening of the fruit. Thus, the first ripe fruit can crumble, and the plant continues to grow and forms new shoots, buds and flowers. Researchers have shown a high correlation between the average daily temperature during the period of "sowing - beginning of flowering" and the development of buckwheat plants $\left(r^{2}=0.84\right)$ and low correlation between the average daily air temperature and ripening of grain $\left(r^{2}=0.53\right)$. It confirms the aforementioned fact that both ripe fruits and flowers can be present on the plant at the same time. Thus, in the middle-ripe varieties the period of "flowering - fruit formation" lasts 3045 days, "fruit formation - ripening" period lasts from 43-44 to 56 days depending on the air temperature, and seed formation (from the beginning of flowering until ripening the fruit) lasti at an average for 21-24 days. It should be noted that the early September frosts that occur in certain years at the end of the growing season in the southern regions can damage buckwheat tops and lead to brashy stalks, premature leaf fall and fruit crumble, especially in varieties with a long growing season.

Generally, the fruit formation takes 20 days, their harvesting take place on 20-25 days and after 10-12 days they have size typical for the variety. After 7-8 days middle dough stage comes ${ }^{26,27}$.

A characteristic reaction of buckwheat plants to adverse thermal conditions is the ability to re-flowering and, accordingly, re-fruiting. This phenomenon is known as "multistory crop". It occurs mainly in the case of high temperatures of air and soil, but after the weakening of the stress factors buckwheat resumes flowering, fruiting and grain filling periods. As

\footnotetext{
${ }^{26}$ Аверчев О.В. Адаптивний потенціал проса, гречки та шляхи його підвищення / О.В. Аверчев, 3.М. Тимофеєв // Таврійський науковий вісник: збірник наукових праць. Вип. 24. - Херсон, 2002. - С. 36-41.

${ }^{27}$ Аверчев А.В. Пайова участь досліджуваних факторів у врожайності гречки повторних посівів на зрошуваних землях півдня України / А.В.Аверчев, Ю.В. Аверчев // Збірник наукових праць Уманської державної академії. - Вип. 53. - Умань, 2001. - С. 40-43.
} 
Berestovsky G. G noted, buckwheat resumes flowering and fruiting, if it rains after the drought. Moreover, the quantity and quality of buckwheat grains are better than during the first-time harvest ${ }^{28}$.

The need for heat for the buckwheat plant of $100 \mathrm{~cm}$ high, with 15leaves on the main stem and with 3-5 branches during the growing season is expressed by the sum of effective temperatures (above $5^{\circ} \mathrm{C}$ ) $1200^{\circ} \mathrm{C}$. Instead, other scientists say that for the "sprout - flowering" period of buckwheat the sum of effective temperatures above $5^{\circ} \mathrm{C}$ is $310^{\circ} \mathrm{C}$, for the period of "flowering - ripening" $-429^{\circ} \mathrm{C}$. And at separate phases of vegetation, the sum of active temperatures for the growth and development of buckwheat is: "sowing - sprouts" - $66-77^{\circ} \mathrm{C}$, "sprouts - flowering" $-310-320^{\circ} \mathrm{C}$, "flowering - ripening" - 420-489, from sowing to ripening $-796-888^{\circ} \mathrm{C}$; for late varieties, this indicator rises to up $1300^{\circ} \mathrm{C}$. However, the required amount of active temperatures, which for buckwheat is $1000-1300^{\circ} \mathrm{C}$, depending on the sowing time, varies slightly ${ }^{29}$.

Concerning the intercrop, according to Populida K.H., favorable climatic conditions for buckwheat with a vegetation period of 70-90 days are created at the sum of temperatures of $1600^{\circ} \mathrm{C}$. Studies have shown a direct relationship between fruit ripening and the sum of effective temperatures $\left(r^{2}=\right.$ 0.93 ), as well as the relationship between temperature summation and the percentage of ripe grains, which is of some importance for determining the harvesting time.

In the zone of unstable moisture, the main factors affecting buckwheat productivity are the combination of heat and moisture, and the hydrothermal coefficient corresponding to the normal development of plants is 0.8 .

\section{Buckwheat and moisture}

Buckwheat prefers moderate and humid climate, but due to a short growing season and high plasticity, it can be grown in a fairly wide range of climatic conditions. However, in summer sowings, in the conditions of the arid Steppe, the soil cap threatens future plants during seed germination, and soil cracking threatens during the emergence of seedlings. Therefore, air and soil moisture are a second vital factor for buckwheat. Thus, with enough soil moisture, post-harvest buckwheat sprouts appear after 3-5 days, and fast and even sprouts appear at $18 \%$ of soil moisture ${ }^{30}$.

\footnotetext{
${ }^{28}$ Калус Ю.А. Влияние условий выращивания и сортовых особенностей гречихи на ее урожай в южной степи Украины: автореф. дис. на соискание уч. степени канд. с.-х. наук: спец. 06.01.09 - растениеводство / Ю.А. Калус. - Одесса, 1973. - 12 с.

${ }^{29}$ Кадирова Ф.Е. Гречиха и просо - ценные крупяные культуры / Ф.Е. Кадирова // Земледелие. - № 3. - 2006. - С. 11.

30 Ефименко Д.Я. Установление оптимальных сроков посева гречихи по уровню температурного режима почвы / Д.Я. Ефименко. - М.: ВДНХ СССР, 1988. - 6 с.
} 
Kohut V. indicated on the close connection between soil moisture, heat and the buckwheat crop during separate periods. At the same time, it is set that for rapid emergence of buckwheat seedlings the moisture reserves in the $0-10 \mathrm{~cm}$ soil layer should be at least $10 \mathrm{~mm}$ at an air temperature not lower than $17 \mathrm{C}$. As the soil temperature and humidity increase, the period from sowing to germination is reduced, but with lower soil moisture, the temperature does not affect the seed germination rate. It should be noted that heavy and prolonged rainfalls, as well as excessive irrigation, are detrimental to young sprouts. Waterlogging leads to the lodging and shetter losses of grain in the second half of the growing season. Scientists believe that soil moisture within $90 \%$ of minimum moisture-holding capacity leads to a slowdown in growth processes. Maintaining soil moisture at $80 \%$ of minimum moisture holding capacity throughout the growing season provides the highest productivity of buckwheat. Other scientists say that it is necessary to maintain soil moisture at $70 \%$ of minimum moisture holding capacity in summer crops of buckwheat, which corresponds to the three irrigations ${ }^{31}$.

A number of researchers point to the influence of soil moisture level on the growth and development of buckwheat plants in different phases of vegetation. The period from the beginning of fruit formation to their browning is called critical for moisture. Scientists believe that the optimum moisture level of the soil during the interphase period of "flowering-fruit formation", which coincides with the beginning of July and lasts until the end of August, guarantees a high yield. At the same time cool evening and night temperatures and high humidity provide the most favorable conditions for plant growth and grain filling.

Buckwheat belongs to water-loving crops: for germination of seeds it requires $45-50 \%$ of water by its weight, and for the formation of $100 \mathrm{~kg}$ of grain and straw plants need $42000 \mathrm{~kg} / \mathrm{ha}$ of water, while wheat requires $23800 \mathrm{~kg}$, and panicum - $230 \mathrm{~kg}$. On the basis of experimental studies conducted in the Odessa region, water consumption for summer crop of buckwheat was $2250 \mathrm{~m}^{3}$ and in dry years it increased to $3152 \mathrm{~m}^{3}$, in wet it decreased to $1478 \mathrm{~m}^{3}$. Moreover, water consumption is different in the periods of growth and development of plants and significantly depends on fertilizers and methods of buckwheat sowing ${ }^{32}$.

The indicator of the water need for plants is usually the transpiration coefficient, which indicates the efficiency of use of moisture and the degree of plasticity to environmental conditions. Transpiration coefficient of buckwheat

31 Кацов И.И. Роль агроклиматического фактора в реализации потенциала сорта Сумчанка / И.И.Кацов, В.М.Клюс, В.Г. Егоров // Зерновые культуры [Мат. I Межгос. конгр. производ. греч.]. - Спец. вып. № 2. - 1993. - С. 35-37.

32 Аверчев О.В. Адаптивний потенціал проса, гречки та шляхи його підвищення / О.В. Аверчев, 3.М. Тимофеєв // Таврійський науковий вісник: збірник наукових праць. Вип. 24. - Херсон, 2002. - С. 36-41. 
is relatively high -541 , while for panicum it ranges from 140 to 390 , for corn - 140-350, for heard wheat - 300-526. ${ }^{33}$ Moreover, with the application of complete mineral fertilizers, the transpiration coefficient is reduced to $70 \%$ compared to unfertilized crops, and in the morning and evening it rises to 700-1300. Scientists have also determined that the greatest water deficit is found in the late-riparian coastal group of varieties, the lowest - in the middleripe mountain group.

In addition, the researchers point out the relatively weak ability of the buckwheat root system to provide significant amount of tops with moisture, since the main mass of buckwheat roots is in a 10-12 cm layer of soil and its share is only $3 \%$ of the total weight of the plant. Due to this, buckwheat is not able to withstand drought in high summer temperatures, and this fact should be taken into account during choosing sowing dates. According to other data, buckwheat of summer crops is able to use soil moisture at a depth of $1.5 \mathrm{~m}$.

The lack of moisture in the soil against the backdrop of air drought and temperatures above $30 \mathrm{C}$ is particularly unfavorable for buckwheat. If hot dry wind occurs, in the course of two or three days the ovaries die off, the leaves lose their turgor, and their absorption of carbon dioxide is more than halved.

It should be noted that the steppe winds, especially in the easterly direction, are destructive not only during the flowers pollination, but also during ripening, when the buckwheat stems are tend to lodging and the fruits are tend to shattering. Because of this, the period from the plumpness to the browning of the grain is vulnerable to the adverse wind regime.

\section{Buckwheat and light}

Researchers refer buckwheat to moderately light-requiring plants. However, buckwheat plants do not tolerate shading, and flowers that have formed in cloudy weather are sterile and underdeveloped, and flowers that have formed in cloudless weather form a full grain ${ }^{34}$.

However, opinions regarding the sensitivity of plants to the lasting light are divergent. Some authors tend to consider buckwheat a plant for a short day, at least they are sensitive to such conditions in the first 15 days after emergence. In a short day (8-12 hours), buckwheat plants bloom faster and ripe, branch more, but give way to growth and productivity of plants grown over a long day. Moreover, the decrease in productivity of such plants is often due to a decrease in their height and leafiness. Other researchers claim that buckwheat is a long-day plant and that optimum light conditions are created

\footnotetext{
${ }^{33}$ Аверчев А.В. Пайова участь досліджуваних факторів у врожайності гречки повторних посівів на зрошуваних землях півдня України / А.В.Аверчев, Ю.В. Аверчев // Збірник наукових праць Уманської державної академії. - Вип. 53. - Умань, 2001. - С. 40-43.

34 Епифанов В.С. Стабильный урожай гречихи / В.С.Епифанов, И.А. Яковлев // Зерновые культуры. - 1989. - № 5. - С. 39.
} 
for the light duration of 17-19 hours a day. However, Aufhammer W. draws attention to the ambiguity of such a statement. He believes that, for certain environmental factors, prolonged light can adversely affect plant development, and gives the data that duration of buckwheat flowering in conditions of a long day at high temperatures extended up to 180 days, and the plants did not bear fruit. Buckwheat study showed that at relatively low temperatures, high clouds and humidity during flowering, buckwheat yields were relatively high - from 600 to $1200 \mathrm{~kg} / \mathrm{ha}^{35}$.

The duration of sunlight has a significant effect on the buckwheat yield in certain periods of development: in the second and third decades of May, the first and second decades of June, the third decade of July and the second decade of August.

Researchers ${ }^{36,37}$ believe that buckwheat response to light duration is neutral. The results of studies conducted in the Rostov region showed that the plasticity relative to light in buckwheat plants of summer crops is relatively high. Buckwheat grows well in both short-day and low-light conditions, as well as in long-day and high-light conditions, which allows it to be grown successfully in post-harvest sowings. In addition to this it was set that the short September days at the end of the post-harvest buckwheat vegetation have some effect on fruit ovaries, but contribute to more even ripening, and this offsets the potential yield losses ${ }^{38,39}$.

\section{Buckwheat and soil and nutrients}

Buckwheat grows on different types of soil, but the most favorable of them are of light and medium mechanical composition. Heavy clay and submerged soil, with insufficient aeration, inhibiting the development of the buckwheat root system, are unusable. Although, there are evidences that buckwheat can normally develop in areas with $0.4-0.6 \mathrm{~m}$ of groundwater level.

Buckwheat shows better performance on poor soils rather than other crops. Fatyga J. also found that buckwheat grows well on soils with a $\mathrm{pH}$ of

35 Аверчев О.В. Адаптивний потенціал проса, гречки та шляхи його підвищення / О.В. Аверчев, 3.М. Тимофеєв // Таврійський науковий вісник: збірник наукових праць. Вип. 24. - Херсон, 2002. - С. 36-41.

${ }^{36}$ Кадирова Ф.Е. Гречиха и просо - ценные крупяные культуры / Ф.Е. Кадирова // Земледелие. - № 3. - 2006. - С. 11.

${ }^{37}$ Калус Ю.А. Влияние условий выращивания и сортовых особенностей гречихи на ее урожай в южной степи Украины: автореф. дис. на соискание уч. степени канд. с.-х. наук: спец. 06.01.09 - растениеводство / Ю.А. Калус. - Одесса, 1973. - 12 с.

${ }^{38}$ Когут В.В. До питання впливу метеорологічних факторів на урожайність гречки сорту Вікторія / В.В. Когут // Збірник наукових праць. - Вип. 8. - Кам'янець-Подільський, 2000. - C. 59-61.

39 Аверчев О.В. Адаптивний потенціал проса, гречки та шляхи його підвищення / О.В. Аверчев, 3.М. Тимофеєв // Таврійський науковий вісник: збірник наукових праць. Вип. 24. - Херсон, 2002. - С. 36-41. 
5 because on such soils it does not respond to liming, and in acid resistance of soil buckwheat is similar to oats and potatoes. In addition, buckwheat does not respond to mineral fertilizers on acid soils. The optimum $\mathrm{pH}$ for buckwheat is in the range of 5-7, and soils with a $\mathrm{pH}$ of 5 and below should be lime ${ }^{40}$.

Obendorf R.L., Slawinska I. express the opinion that the use of high nitrogen soils is inappropriate because buckwheat is relatively undemanding to the level of nutrition, but because of the considerable nutrient application in soil, it affects subsequent crop rotations. Thus, the application of nutrients with buckwheat grain at a yield of $13 \mathrm{~kg} / \mathrm{ha}$ in the conditions of the state of Minnesota (USA) is: nitrogen - 10, phosphorus $-4 \mathrm{~kg}$, potassium $-14 \mathrm{~kg} / \mathrm{ha}$, and at a yield of $22 \mathrm{~kg} / \mathrm{ha}-44,8,22,4$ and $14.6 \mathrm{~kg} / \mathrm{ha}$, respectively, which corresponds to the application of it with sunflower seeds at an equivalent yield.

Buckwheat root system is characterized by intensive absorption of nutrients. Despite the fact that the buckwheat root system is twice less in length than in oats and 10 times smaller than in potatoes, the solubility of its roots compared to winter rye and spring wheat is 23 and 12 times higher, respectively. Thus, according to Marchuk I.U., in the first one and a half months after sowing, buckwheat absorbs more than half of the required amount of macroelements: $55-65 \%$ of nitrogen, $40-45 \%$ of phosphorus and $60-70 \%$ of potassium accumulate before the flowering phase in plants.

Despite the active absorption of nutrients from the soil, buckwheat plant is sensitive to the additional mineral elements. Perhaps the high buckwheat demand for nutrition is due to its inherent ability to form both vegetative and reproductive organs throughout the growing season. However, a number of researchers have concluded that buckwheat needs nitrogen nutrition first.

Thus, with the content of nitrogen of $8 \mathrm{mg} / \mathrm{kg}$ of soil, the yield of buckwheat increases, but with a further increase of nitrogen introduction (from 8 to $60 \mathrm{mg}$ ) it decreases. According to Anokhin A.N., high doses of nitrogen dramatically reduce plant resistance to lodging and reduce the nectar productivity of flowers, as well as provoke plant damage by botritis disease in late sowings ${ }^{41}$.

Since nitrogen fertilizers are effective only when other elements are present in the soil, there is a need for other fertilizers. This pattern is particularly relevant for phosphorus fertilizers in the southern areas where soils are well supplied with potassium. Thus, Marchuk I.U., Moiseenko A.A., Naumkin V.N. believe that in the second half of the growing season (fruit formation and grain filling) buckwheat requires a large amount of phosphorus.

${ }^{40}$ Алексеєва О.С. Гречка / О.С. Алексеєва. - К.: Урожай, 1976. - 131 с.

41 Кацов И.И. Роль агроклиматического фактора в реализации потенциала сорта Сумчанка / И.И. Кацов, В.М. Клюс, В.Г. Егоров // Зерновые культуры [Мат. I Межгос. конгр. производ. греч.]. - Спец. вып. № 2. - 1993. - С. 35-37. 
Moreover, scientists are convinced of the need of their use in the same doses as for wheat. Pannikov V.D, Podvezko V.V., Ronsal G.A. indicate the positive effect of phosphorus fertilizers in the southern carbonate chernozem, southern chernozem and dark chestnut soils, bogara and other soils.

The presence of nitrogen fertilizers in buckwheat sowings enhances the individual efficiency of phosphorus and potassium. Moreover, the combination of nitrogen and phosphorus fertilizers can reduce the negative effects of extreme environmental factors. However, according to Tkalich I.D. research, nitrogen-phosphorus nutrition of post-harvested buckwheat, even at a low level, does not contribute to increasing its productivity, but only increases the cost and energy consumption of production. Instead, in the experiments of Averchev O.V. application of this rate of fertilizers ensured a maximum yield of buckwheat in the irrigated sowings of the Kherson region $2050 \mathrm{~kg} / \mathrm{ha}$. And the share of nitrogen-phosphorus fertilizers $\mathrm{N}_{45} \mathrm{P}_{30}$ norm in the formation of buckwheat yield was key and it was 30-43\%.

Existing data on the use of potash fertilizers under buckwheat are quite controversial. At the beginning of the last century, the works of Pryanishnikov D.N., Chirikov F.V. and other researchers found that potassium plants can absorb potassium from the mineral part of the soil - silicates and aluminosilicates, and not only its mobile forms, but also potassium in the crystal lattice. Low potassium efficiency on different types of soil or even its negative effect on buckwheat plants is indicated in a lot of works. The low impact of potash fertilizers in the conditions of dark-chestnut residual-saline soils of the Skadovsky region were discovered in the works of Ushkarenko V.O.

The application of complete fertilizer is considered more effective for buckwheat in all types of soils, however, most references refer to the Foreststeppe zone of Ukraine. Moreover, the greatest sensitivity of buckwheat is found on poor sod-podzol and light gray soils in conditions of sufficient moisture. Thus, complete mineral fertilizer provides grain yield increase in Lviv, Chernihiv, Rivne, Podillya, Vinnytsia, Sumy and Poltava regions.

\section{CONCLUSIONS}

Buckwheat is not demanding for growing conditions. This short-day crop responds to daylight savings in the second half of summer; it is a warm and light-loving plant, adapted to short-term droughts and moderate fertility soils. The realization of maximum productivity of cereal crops in specific growing conditions is ensured first of all by satisfying the basic agrobiological requirements of the crop. Due to this, increase of indicators, which are closely correlated with the yield, can be achieved by minimizing the effects of those factors that negatively affect the growth and development of plants in the respective phases of the growing season. Formation of these components requires the development of certain agrotechnical measures. 


\section{SUMMARY}

The article deals with the issues of adaptive potential of buckwheat to environmental conditions. The reaction of buckwheat to the temperature and water regime is established. In the zone of unstable moisture, the main factors affecting buckwheat productivity are the combination of heat and moisture, and the hydrothermal coefficient corresponding to normal plant development is 0.8 . The duration of sunlight has a significant effect on the buckwheat yield in certain periods of development: in the second and third decades of May, the first and second decades of June, the third decade of July and the second decade of August. The buckwheat relation to soil and nutrients are discussed. Buckwheat grows on different types of soil, but the most favorable of them are soils of light and medium mechanical composition. Heavy clayey and submerged soils with insufficient aeration that inhibit the development of the buckwheat root system are unsuitable, although there is evidence that buckwheat can develop normally in areas where groundwater levels are $0.4-0.6 \mathrm{~m}$.

\section{REFERENCES}

1.Погріщук Б.В. Організаційно-економічні умови функціонування зернопродуктового підкомплексу України: аспекти оптимізації [Текст] / Б.В. Погріщук // АгроСвіт. - 2010. - № 4. - С. 13-17.

2. Крестьянникова Т.М. Пожнивное выращивание гречихи / Т.М. Крестьянникова / [Под ред. И.Н. Елагина] // Биология и возделывание гречихи. - М.: Сельхозиздат, 1962. - С. 273-302.

3. Кадирова Ф.Е. Гречиха и просо - ценные крупяные культуры / Ф.Е. Кадирова // Земледелие. - № 3. - 2006. - С. 11.

4. Xianshi G. Yingyong shengtai xuebao / G.Xianshi // Chin. J. Appl. Ecol. - 1999. - V. 10. - № 5. - P. 563-566.

5. Когут В.В. До питання впливу метеорологічних факторів на урожайність гречки сорту Вікторія / В.В. Когут // Збірник наукових праць. - Вип. 8. - Кам'янець-Подільський, 2000. - С. 59-61.

6. Кацов И.И. Роль агроклиматического фактора в реализации потенциала сорта Сумчанка / И.И. Кацов, В.М. Клюс, В.Г. Егоров // Зерновые культуры [Мат. I Межгос. конгр. производ. греч.]. - Спец. вып. № 2. - 1993. - С. 35-37.

7. Аверчев О.В. Адаптивний потенціал проса, гречки та шляхи його підвищення / О.В. Аверчев, 3.М. Тимофеєв // Таврійський науковий вісник: збірник наукових праць. - Вип. 24. - Херсон, 2002. - С. 36-41.

8. Калус Ю.А. Влияние условий выращивания и сортовых особенностей гречихи на ее урожай в южной степи Украины: автореф. дис. ... канд. с.-х. наук: спец. 06.01.09 - растениеводство / Ю.А. Калус. Одесса, 1973. - 12 с. 
9. Аверчев А.В. Пайова участь досліджуваних факторів у врожайності гречки повторних посівів на зрошуваних землях півдня України / А.В. Аверчев, Ю.В. Аверчев // Збірник наукових праць Уманської державної академії. - Вип. 53. - Умань, 2001. - С. 40-43.

10. Кадирова Ф.Е. Гречиха и просо - ценные крупяные культуры / Ф.Е. Кадирова // Земледелие. - № 3. - 2006. - С. 11.

11. Єфіменко Д.Я. Круп'яні культури / Д.Я. Єфіменко, I.В.Яшовський, Б.І.Лактіонов, І.М. Фрич / [За ред. І.В. Яшовського]. - К.: Урожай, 1982. - 160 с.

12. Ефименко Д.Я. Установление оптимальных сроков посева гречихи по уровню температурного режима почвы / Д.Я. Ефименко. М.: ВДНХ СССР, 1988. -6 c.

13. Епифанов В.С. Стабильный урожай гречихи / В.С. Епифанов, И.А. Яковлев // Зерновые культуры. - 1989. - № 5. - С. 39.

14. Дедышин Я.И. Влияние условий выращивания на урожай и качество зерна гречихи / Я.И. Дедышин // Селекция, семеноводство и технология производства гречихи. - Черновцы: Буковина, 1997. Вып. 9. - 224 с.

15. Гораш О.С. Екологічна різноякісність насіння гречки / О.С. Гораш // Збірник наукових праць. - Вип. 8. - Кам'янецьПодільський, 2000. - С. 26-29.

16. Борисова Н.А. Урожайность гречихи по влагообеспеченности на юге Центрального региона Нечерноземной зоны / Н.А. Борисова, М.К. Каюмов // Научные труды РГАЗУ. - М., 2002. - С. 44-46.

17. Алексеєва О.С. Гречка / О.С. Алексеєва. - К.: Урожай, 1976. $131 \mathrm{c}$.

\section{Information about the author:} Averchev O. V.,

Doctor of Agricultural Science, Professor, Prorector for Scientific Work and International Activity, State Higher Educational Institution "Kherson State Agricultural University" 23, Stritenskaya str., Kherson, 73000, Ukraine 